\title{
RHEUMATOID FACTORS IN PRIMARY AND REACTIVE MACROGLOBULINAEMIA
}

\author{
BY \\ F. KLEIN AND P. MATTERN \\ From the Department of Rheumatology, University Hospital, Leyden, the Netherlands, \\ and the Institut Pasteur, Dakar, Senegal
}

The occurrence of $\operatorname{IgM}\left(=\beta_{2 \mathrm{M}}\right)$-globulins capable of reacting with $\operatorname{IgG}(=7 \mathrm{~S}-\gamma)$-globulin, the socalled rheumatoid factors, is not restricted to rheumatoid arthritis, but has been reported in a variety of conditions unrelated to the collagen diseases. The importance of these "false positive" reactions lies in the possibility of obtaining more information about the origin of the rheumatoid factors by studying different biological conditions under which these factors can arise.

Many of the diseases associated with false positive reactions in the tests for rheumatoid factors belong to the group of chronic infections. Thus a high incidence of false positive reactions has been reported in syphilis (Bloomfield, 1960), leprosy (Cathcart, Williams, Ross, and Calkins, 1961), kala-azar (Kunkel, Simon, and Fudenberg, 1958), tuberculosis (Singer, Plotz, Peralta, and Lyons, 1962) and chronic bronchitis (Bonomo, Tursi, and Pinto 1963), although in none of these instances could this be confirmed by Valkenburg and Hijmans (unpublished). The experimental production of rheumatoid factors by prolonged immunization with certain bacteria by Eyquem, Guyot-Jeannin, and Podliachouk (1959) and Abruzzo and Christian (1961), and with purified proteins either alone or in combination with their specific antibody (Aho and Wager, 1961) has provided some basis for the expectation that chronic infections could be accompanied by the presence of rheumatoid factors. The explanation in all such cases would then be that a prolonged stimulation with $\gamma$-globulin which is altered by its binding to an antigen, produces rheumatoid factors as antibodies against the $\gamma$-globulin part of immune complexes. An interesting example is subacute bacterial endocarditis (Williams and Kunkel, 1962), in which the antigen is being constantly fed into the circulation, a situation which is analogous to the experiments of Eyquem and others (1959).

In a search for other diseases associated with the occurrence of rheumatoid factors, trypanosomiasis drew our attention because it is an infection of long duration with the peculiarity that there is a permanently high level of IgM-globulin in the serum, at least part of which is of antibody nature (Mattern, Masseyeff, Michel, and Peretti, 1961). As would be expected these IgM-globulins are heterogeneous in electrophoresis in contrast to the paraproteins of Waldenström's macroglobulinaemia, to which they bear a certain resemblance in ultracentrifugation (Mattern, Klein, Hijmans, and Radema, 1963). Positive rheumatoid serology might be expected here, in view of the chronic nature of the disease and because of the tendency, which is perhaps dependent on special properties of the antigen, to produce a large amount of IgM antibodies not only at the beginning of the infection but during a prolonged period. If certain properties of the antigen favour the formation of IgM antibodies, this might also apply to the formation of rheumatoid factors. In this connexion it should be remembered that the opinion has been expressed that rheumatoid factor reactions occur particularly in conditions in which IgM-globulins of reactive origin are prominent (Bartfeld, 1960).

This hypothesis is opposed by the reported high incidence (Hammack and Holley, 1961; Waldenström, Winblad, Hällén and Liungman, 1964) of positive reactions in Waldenström's macroglobulinaemia, a disease in which the pathological IgMglobulin is usually assumed not to be of reactive origin. These macroglobulins show a characteristic narrow zone in electrophoresis which indicates the homogeneity of these so-called paraproteins, in contrast to the well-known heterogeneity produced by multiple antibodies.

This report deals with the serological investigation of trypanosomiasis sera in comparison with sera from diseased controls. Sera from patients with chronic splenomegaly were also included in this study, since Francq, Eyquem, Podliachouk, and Jacqueline (1960) reported that such sera show false positive rheumatoid serology. In this typically African syndrome, described by Charmot, Demarchi, Orio, Reynaud, and Vargues (1959), the serum sometimes contains large amounts of IgM-globulin, the origin and function of which is unknown, but which in electrophoresis shows the characteristic heterogeneity of antibodies. In order to investigate 
the other, non-reactive aspect of macroglobulinaemia, a number of sera containing IgM paraproteins, mainly from cases of Waldenström's macroglobulinaemia, were compared with sera from elderly people and from patients suffering from various unrelated diseases.

\section{Material and Methods}

Sera from patients suffering from trypanosomiasis caused by $T$. gambiense chronic splenomegaly and the sera of diseased controls were all collected at the Institut Pasteur of Dakar, Senegal.

For trypanosomiasis the clinical diagnosis was always confirmed by demonstrating the presence of the infecting organism in the cerebrospinal fluid. In difficult cases, quantities of cerebrospinal fluid up to $100 \mathrm{ml}$., obtained by suboccipital puncture were centrifuged and the sediment injected into a Gambian rat (Cricetomys gambianus WATERHOUSE), an animal which is very sensitive to the trypanosome. Sometimes repeated examinations were needed to obtain the necessary confirmation. In all such cases detection of IgM in the cerebrospinal fluid by means of immuno-electrophoresis served as an indicator. In fact an increased level of IgM in this fluid seems to be pathognomonical for trypanosomiasis in the nervous phase (Mattern, 1962, 1964). For chronic splenomegaly only clinical criteria were used, essentially based on the presence of a chronically enlarged spleen without a proved infectious aetiology. Control material included cases of various unrelated diseases from the same region, among them a considerable number of neuropsychiatrical patients. Many of the control sera had a IgM-globulin content considerably above normal, which is by no means exceptional for pathological sera in Africa.

Sera from patients suffering from Waldenström's macroglobulinaemia were obtained from the Departments of Internal Medicine of the University Hospitals of Leyden and Utrecht. Diagnoses were confirmed by agar electrophoresis and immunoelectrophoresis with specific antisera and by analytical ultracentrifugation. All but three patients were above 55 years of age and half of them above 65 (see Table IV). Control sera from elderly persons aged 55-64 years were obtained from a random sample of the population of Rotterdam (Ball, De Graaff, Valkenburg, and Westendorp Boerma, 1962). Sera of diseased controls were collected at the Departments of Internal Medicine and Rheumatology of the University Hospital, Leyden.

As far as possible cases of rheumatoid arthritis were excluded from all the groups under investigation.

Latex-fixation tests with human gamma globulin were performed as described by Valkenburg (1963a). For the Waaler-Rose tests human erythrocytes sensitized with rabbit gamma globulin were used (Valkenburg, 1963b).

Reduction was carried out by adding 2-mercaptoaethanol to the serum under investigation to a final concentration of $0.02 \mathrm{M}$ before the serological tests were performed.

Cold agglutinins were demonstrated by observing the agglutination of human $\mathrm{O} \mathrm{Rh}^{+}$red cells at $4^{\circ} \mathrm{C}$. under a microscope and by performing the Waaler-Rose test as mentioned above with unsensitized red cells.

Estimations of the IgM-globulin content of the sera were made by means of a diffusion test against antiIgM-globulin serum as described by Mattern and others (1961). The final dilution giving a visible precipitation line was compared with that of a mixture of 127 normal sera of people from the same region.

\section{Results}

In Table I the results of the serological tests done on the reactive types of macroglobulinaemia and their controls are presented. Increased IgMglobulin means an estimated total IgM-globulin content of at least twice the normal, as judged from a comparison with a pool of normal sera. For trypanosomiasis the division between normal and increased IgM-globulin was not made, since nearly all of these sera were found to have a considerably increased IgM-globulin content. The titres are divided into three groups. Latex titres $>640$ and Waaler-Rose titres $>16$ are judged clinically significant when used for the diagnosis of rheumatoid arthritis. These limits are chosen so that the largest possible number of rheumatoid arthritis cases belongs to the positive group and the smallest to the

TABLE I

SEROLOGICAL TESTS IN REACTIVE MACROGLOBULINAEMIAS AND CONTROLS

\begin{tabular}{|c|c|c|c|c|c|c|c|c|c|c|c|c|c|c|}
\hline \multirow{3}{*}{\multicolumn{2}{|c|}{ Disease }} & \multirow{3}{*}{$\begin{array}{c}\text { Number of } \\
\text { Cases }\end{array}$} & \multicolumn{6}{|c|}{ Titre of Latex-fixation Test } & \multicolumn{6}{|c|}{ Titre of Waaler-Rose Test } \\
\hline & & & \multicolumn{2}{|c|}{$<20$} & \multicolumn{2}{|c|}{$20-640$} & \multicolumn{2}{|c|}{$\begin{array}{c}1,280 \text { or } \\
\text { higher }\end{array}$} & \multicolumn{2}{|c|}{$<4$} & \multicolumn{2}{|c|}{ 4-16 } & \multicolumn{2}{|c|}{32 or higher } \\
\hline & & & No. & $\begin{array}{l}\text { Per } \\
\text { cent. }\end{array}$ & No. & $\begin{array}{c}\text { Per } \\
\text { cent. }\end{array}$ & No. & $\begin{array}{c}\text { Per } \\
\text { cent. }\end{array}$ & No. & $\begin{array}{c}\text { Per } \\
\text { cent. }\end{array}$ & No. & $\begin{array}{c}\text { Per } \\
\text { cent. }\end{array}$ & No. & $\begin{array}{l}\text { Per } \\
\text { cent. }\end{array}$ \\
\hline \multicolumn{2}{|c|}{ Trypanosomiasis } & 66 & 48 & $72 \cdot 8$ & 15 & $22 \cdot 7$ & 3 & $4 \cdot 5$ & 24 & $36 \cdot 4$ & 30 & $45 \cdot 4$ & 12 & $18 \cdot 2$ \\
\hline \multirow[b]{2}{*}{ Splenomegaly } & Increased IgM & 39 & 21 & $53 \cdot 8$ & 14 & $35 \cdot 9$ & 4 & $10 \cdot 3$ & 20 & $51 \cdot 2$ & 15 & $38 \cdot 5$ & 4 & $10 \cdot 3$ \\
\hline & Normal IgM & 39 & 31 & $79 \cdot 5$ & 6 & $15 \cdot 4$ & 2 & $5 \cdot 1$ & 33 & $84 \cdot 6$ & 3 & $7 \cdot 7$ & 3 & $7 \cdot 7$ \\
\hline \multirow[t]{2}{*}{ Unrelated Diseases } & Increased IgM & 36 & 25 & $69 \cdot 5$ & 8 & $22 \cdot 2$ & 3 & $8 \cdot 3$ & 28 & $77 \cdot 8$ & 8 & $22 \cdot 2$ & 1 & $2 \cdot 8$ \\
\hline & Normal IgM & 80 & 69 & $86 \cdot 2$ & 8 & 10 & 3 & $3 \cdot 8$ & 72 & 90 & 7 & $8 \cdot 8$ & 1 & $1 \cdot 2$ \\
\hline
\end{tabular}


negative group. It is doubtful whether such a division has any meaning here, since we are not dealing with rheumatoid arthritis. A comparison of all sera reacting with any observable titre in these tests seems to have more meaning and is actually made here. For purposes of comparison with the literature the number of "clinically" positive tests is also given.

Table II shows the frequency distribution of the titres found. The distribution of Waaler-Rose titres in trypanosomiasis suggests a biphasic curve with a maximum at 16 . Leaving out all "subclinical" titres $(\leqslant 16)$ would then mean that a major part of the data was discarded. In general the latex titres tend to be distributed more evenly. It has been found by Klein and Valkenburg (unpublished) that about 60 per cent. of human sera contain small amounts of rheumatoid factor-like substances, the effect of which in the latex test is suppressed by a thermolabile inhibitor. Since many of the sera used in this study were frozen and thawed several times, it is possible that this inhibitor was partially inactivated, rendering the frequency distribution patterns difficult to interpret.

Only six trypanosomiasis sera were latex positive and Waaler-Rose negative $(\mathrm{L}+\mathrm{R}-)$, whereas thirty sera were Waaler-Rose positive only $(\mathrm{L}-\mathrm{R}+)$. In the splenomegaly sample there were eleven $\mathbf{L}+\mathbf{R}-$ and ten $\mathbf{L}-\mathbf{R}+$ sera. The control group contained eleven $\mathrm{L}+\mathrm{R}-$ and eight $\mathrm{L}-\mathrm{R}+$ sera.
In Table III (opposite) various groups are compared statistically. The control group for trypanosomiasis consisted of all available unrelated diseases (except splenomegaly) irrespective of their IgMglobulin level. For splenomegaly the control group consisted of people with the same disease but with normal IgM levels. Within the control groups the only common criterion of the two subgroups was a normal or increased IgM-globulin level.

Positive tests for rheumatoid factors could possibly be caused not only by the reactions of these factors themselves but also by immuno-conglutinins and, in the case of the Waaler-Rose test, by cold agglutinins. Both these serum components have been found in trypanosomiasis. Yorke (1911) described cold agglutinins in sera from such patients, and Ingram, Barber, McLean, Soltys, and Coombs (1959) found high levels of immuno-conglutinins in rabbits immunized with $T$. Brucei.

All Waaler-Rose positive sera and twelve WaalerRose negative trypanosomiasis sera were tested for cold agglutinins, with completely negative results.

Immuno-conglutinin reactions were excluded by performing the serological tests with positive sera in which the substrate of the reaction, i.e. complement, was inactivated by heating the sera for $20 \mathrm{~min}$. at $56^{\circ} \mathrm{C}$. Eight trypanosomiasis sera and four splenomegaly sera remained positive in the WaalerRose test after this treatment.

After treatment of the sera with 2-mercaptoaethanol, the positive reactions disappeared in every

FREQUENCY DISTRIBUTIO

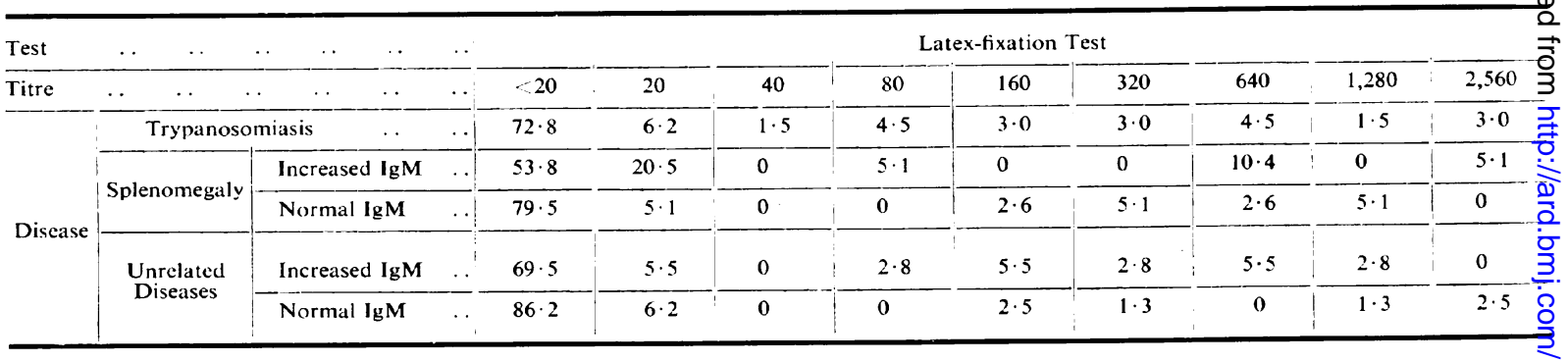

\begin{tabular}{|c|c|c|c|c|c|c|c|c|c|c|c|c|c|c|c|}
\hline Test & . & .. & . & $\ldots$ & . & $\cdots$ & & & & \multicolumn{3}{|c|}{ Latex-fixation Test } & & & \\
\hline Titre & $\cdots$ & . & . & $\cdots$ & $\cdots$ & $\cdots$ & $<20$ & 20 & 40 & 80 & 160 & 320 & 640 & 1,280 & 2,560 \\
\hline \multirow{3}{*}{ Series } & \multicolumn{5}{|c|}{$\begin{array}{l}\text { Waldenström's } \\
\text { Macroglobulinaemia.. }\end{array}$} & .. & $62 \cdot 8$ & $5 \cdot 7$ & 0 & $2 \cdot 9$ & $2 \cdot 9$ & $2 \cdot 9$ & $14 \cdot 2$ & $2 \cdot 9$ & 0 \\
\hline & \multicolumn{4}{|c|}{ Elderly Controls } & . & $\cdots$ & 82 & 0 & 0.4 & 0 & $3 \cdot 6$ & $4 \cdot 0$ & $4 \cdot 0$ & $3 \cdot 2$ & $2 \cdot 8$ \\
\hline & \multicolumn{4}{|c|}{ Unrelated Diseases } & & $\ldots$ & $75 \cdot 5$ & 0 & 0 & 0 & $4 \cdot 9$ & $4 \cdot 0$ & $2 \cdot 9$ & $2 \cdot 9$ & $2 \cdot 6$ \\
\hline
\end{tabular}


TABLE III

COMPARISON OF GROUPS FROM TABLE I

\begin{tabular}{|c|c|c|c|}
\hline Comparison & & Latex-fixation Test (all titres $\geqslant 20$ ) & Waaler-Rose Test (all titres $\geqslant 4$ ) \\
\hline Trypanosomiasis versus Unrelated diseases & . & $\begin{array}{l}X_{(1)}^{2}=1 \cdot 247 \\
0 \cdot 20<P<0 \cdot 30\end{array}$ & $\begin{array}{l}\chi_{(1)}^{2}=43 \cdot 617 \\
P<0.0005\end{array}$ \\
\hline Splenomegaly with increased IgM versus normal IgM & $\cdots$ & $\begin{array}{l}\chi_{(1)}^{2}=4 \cdot 673 \\
0 \cdot 025 \therefore P \cdot 0 \cdot 05\end{array}$ & $\begin{array}{l}\chi_{(1)}^{2}=8.477 \\
0.001<P<0.005\end{array}$ \\
\hline Unrelated diseases with increased IgM versus norma! IgM & $\cdots$ & $\begin{array}{l}X_{(1)}^{2}=3.535 \\
0.05<P<0.10\end{array}$ & $\begin{array}{l}\chi_{(1)}^{2}=2 \cdot 176 \\
0 \cdot 10<P<0 \cdot 20\end{array}$ \\
\hline
\end{tabular}

instance just as they do in classical rheumatoid factor reactions.

Table IV lists the results of the investigation of sera from patients with Waldenström's macroglobulinaemia and from the control groups. The frequency distribution of latex titres in Walden- ström's macroglobulinaemia (Table V) suggests a biphasic curve although the numbers are too small for any definite conclusions to be drawn. Such indications are absent in the control groups.

Table VI (overleaf) gives the results of the statistical analysis. In the diseased control group not

TABLE IV

SEROLOGICAL TESTS IN WALDENSTRÖM'S MACROGLOBULINAEMIAS AND CONTROLS

\begin{tabular}{|c|c|c|c|c|c|c|c|c|c|c|c|c|c|c|c|}
\hline \multirow{3}{*}{\multicolumn{3}{|c|}{ Series }} & \multirow{3}{*}{$\begin{array}{c}\text { Number of } \\
\text { Cases }\end{array}$} & \multicolumn{6}{|c|}{ Titre of Latex-fixation Test } & \multicolumn{6}{|c|}{ Titre of Waaler-Rose Test } \\
\hline & & & & \multicolumn{2}{|c|}{20} & \multicolumn{2}{|c|}{$20-640$} & \multicolumn{2}{|c|}{$\begin{array}{c}1,280 \text { or } \\
\text { higher }\end{array}$} & \multicolumn{2}{|c|}{$<4$} & \multicolumn{2}{|c|}{$4-16$} & \multicolumn{2}{|c|}{32 or higher } \\
\hline & & & & No. & $\begin{array}{l}\text { Per } \\
\text { cent. }\end{array}$ & No. & $\begin{array}{c}\text { Per } \\
\text { cent. }\end{array}$ & No. & $\begin{array}{c}\text { Per } \\
\text { cent. }\end{array}$ & No. & $\begin{array}{c}\text { Per } \\
\text { cent. }\end{array}$ & No. & $\begin{array}{c}\text { Per } \\
\text { cent. }\end{array}$ & No. & $\begin{array}{c}\text { Per } \\
\text { cent. }\end{array}$ \\
\hline \multicolumn{3}{|c|}{ Waldenström`s Macroglobulinaemia } & 35 & 22 & $62 \cdot 8$ & 9 & $25 \cdot 7$ & 4 & $11 \cdot 5$ & 22 & $68 \cdot 8$ & 11 & $31 \cdot 4$ & 2 & $5 \cdot 7$ \\
\hline Elderly Controls & $\cdots$ & $\cdots$ & 247 & 20 & 82 & 30 & $12 \cdot 1$ & 16 & $6 \cdot 5$ & 229 & $92 \cdot 8$ & 8 & $3 \cdot 2$ & 10 & $4 \cdot 0$ \\
\hline Cnrelated Diseases & $\ldots$ & . & 102 & 77 & $75 \cdot 5$ & 12 & $11 \cdot 7$ & 13 & $12 \cdot 7$ & & & not & Jone & & \\
\hline
\end{tabular}

II

OF TITRES (PER CENT.)

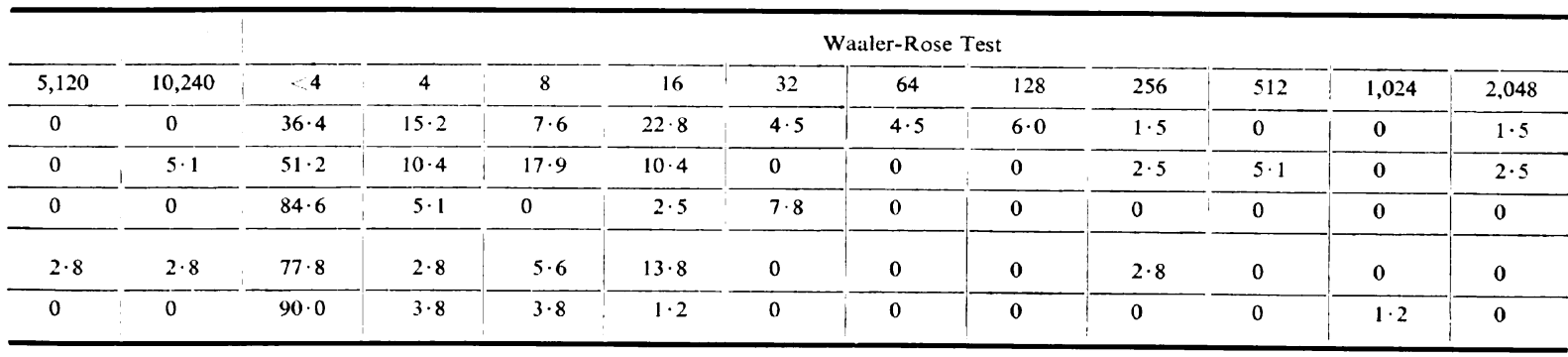

$\mathrm{v}$

OF TITRES (PER CENT.)

\begin{tabular}{|c|c|c|c|c|c|c|c|c|c|c|c|c|}
\hline \multirow[b]{2}{*}{5,120} & \multirow[b]{2}{*}{10,240} & \multicolumn{11}{|c|}{ Waaler-Rose Test } \\
\hline & & $<4$ & 4 & 8 & 16 & 32 & 64 & 128 & 256 & 512 & 1,024 & 2,048 \\
\hline 0 & $5 \cdot 7$ & $68 \cdot 8$ & $14 \cdot 2$ & $11 \cdot 4$ & 0 & 0 & 0 & 0 & $2 \cdot 8$ & 0 & 0 & $2 \cdot 8$ \\
\hline 0 & 0 & $92 \cdot 8$ & 0 & $2 \cdot 4$ & $0 \cdot 8$ & $0 \cdot 4$ & 0.4 & $1 \cdot 2$ & 0.4 & $1 \cdot 2$ & 0 & 0.4 \\
\hline $2 \cdot 9$ & $4 \cdot 0$ & & & & & & & & & & & \\
\hline
\end{tabular}


TABLE VI

COMPARISON OF GROUPS FROM TABLE IV

\begin{tabular}{|c|c|c|c|}
\hline Comparison & & Latex-fixation Test (all titres $\geqslant 20$ ) & Waaler-Rose Test (all titres $\geqslant 4$ ) \\
\hline Waldenström's macroglobulinaemia versus Elderly controls & $\cdots$ & $\begin{array}{l}\chi_{(1)}^{2}=5.285 \\
0.010<P<0.025\end{array}$ & $\begin{array}{l}\chi_{(1)}^{2}=24 \cdot 959 \\
\mathbf{P}<0.0005\end{array}$ \\
\hline Waldenström's macroglobulinaemia versus Unrelated diseases & $\cdots$ & $\begin{array}{l}\chi_{(1)}^{2}=1.492 \\
0 \cdot 20<P<0.30\end{array}$ & not done \\
\hline
\end{tabular}

enough Waaler-Rose tests were done to allow a valid comparison.

In the macroglobulinaemia sample there were nine $\mathbf{L}+\mathbf{R}-$ and seven $\mathbf{L}-\mathbf{R}+$ sera. The elderly control group contained $34 \mathrm{~L}+\mathrm{R}-$ and seven $\mathbf{L}-\mathbf{R}+$ sera.

\section{Discussion}

From the results of the serological tests it appears that an important, statistically significant increase in anti-IgG factors occurs in sleeping sickness, but that these factors react predominantly with rabbit $\gamma$-globulin. Although sera reacting only in the Waaler-Rose test can be found occasionally, this phenomenon has not yet been associated with a specific disease. It is sometimes stated that a positive latex-fixation test is found more often in non-rheumatoid sera than a reaction in the WaalerRose test or in both tests (Bartfeld, 1960, but see Hijmans, 1963). Valkenburg (1963c) found an increase in favour of the latex test in tropical areas with poor health status. Unusual as these reactions of trypanosomiasis sera may be, they are nevertheless more in line with the results of autoimmunization experiments like those of Milgrom and Witebsky (1960), who immunized rabbits with their own $\gamma$-globulin and found reactions with a predilection for heterologous (human) $\gamma$-globulin. The hypothesis that the positive reactions in trypanosomiasis are the result of antibody formation against the $\gamma$-globulin part of antigen-antibody complexes, would be supported by the observation that the freely circulating exo-antigen of the trypanosome seems to be firmly bound to the $\gamma$-globulin of the host (Weitz, 1963). It would then be expected that rheumatoid factors would appear only after prolonged immunization, as in the experiments of Eyquem and others (1959) and Abruzzo and Christian (1961) and would decrease after treatment. In contradiction to this, two cases of trypanosomiasis from our samples, which had an unusually acute course, both showed a positive Waaler-Rose test (titres 16 and 128) 5 weeks after the infecting sting. Furthermore, though the positive reaction was seen to disappear during treatment in three cases, it remained constant 7 months after starting treatment in one case and actually increased in another case. Since high levels of IgM-globulin may persist for a long time after beginning treatment, it is desirable to follow up more cases during longer periods to reach more definite conclusions. In the meantime the hypothesis may be tentatively put forward that the situation in sleeping sickness is a natural analogy to the experiments of Eyquem and others, mentioned in the introduction.

The serological investigation of other macroglobulinaemias of presumably reactive origin (a case which is not yet proven for splenomegaly) reveals an association of positive tests for rheumatoid factors with increased IgM-globulin level, with a much lower degree of significance. Within the splenomegaly groups, this association is most pronounced in the Waaler-Rose test, whereas an excess of positive latex tests is seen at a much less significant level for the diseased controls.

These results suggest that rheumatoid factors may occur more often when reactive IgM-globulins are present in increased amounts, but that the nature of the antigen may play an important role, because the degree of significance differs considerably from one disease to another.

All positive reactions can be abolished after treatment of the sera with $0.01 \mathrm{M}$ 2-mercaptoaethanol. This is usually taken as an indication that IgMglobulins are responsible for the serological reactions (see Grubb and Swahn, 1958). The levels of IgMglobulins which were present in the sera investigated leave room for doubt. It was found that many, but not all, of the sera in which a high level of IgMglobulin was found on the first examination in Dakar, contained much less on subsequent analysis in Leyden. Repeated freezing and thawing caused no further decrease, so that the suspicion arises that the IgM-globulins are partly present in a very labile form, and partly in a more stable variety. This problem is now under investigation, but it may be supposed that serological examination immediately after taking the sera might have given higher figures. 
It is also for this reason that no attempt was made to look for a correlation between the magnitude of the increase in IgM-globulin content and the occurrence of positive serological reactions. On first sight such a correlation would seem to be absent.

Earlier investigators (Yorke, 1911) reported the incidence of cold agglutinins in trypanosomiasis sera. These could cause an agglutination of erythrocytes, indistinguishable from a true positive Waaler-Rose test. None of our positive sera however, contained more than traces of cold agglutinins, so that this possibility can be ruled out. Agglutination of erythrocytes could also be caused by immunoconglutinins, the occurrence of which has been reported by Ingram and others (1959) in experimental infections of rabbits with $T$. Brucei. Immunoconglutinins are antibodies against complement (Coombs, Coombs, and Ingram, 1961) which are supposed to arise by the same mechanism as the rheumatoid factors in this study. The possibility of false agglutinations in the Waaler-Rose test depends on the presence of complement in the tested sera, and can be checked easily by inactivating these sera. Since the sera that were tested in this way remained positive after inactivation, the participation of immunoconglutinins in the agglutination reactions seems to be ruled out as well.

The IgM paraproteinaemias belong to a different group, because the macroglobulins here are usually considered to arise as the result of a malignant growth of an IgM-globulin-producing cell clone. Ritzmann and Levin (1962) supposed that false positive reactions would occur if the proliferating clone happened to be of a rheumatoid factorproducing kind, thus accounting for the high incidence of positive rheumatoid serology that has been reported for this group. If this were true, one would expect either a very strong reaction, because of the high concentration of IgM-globulin in these sera, or no reaction at all. Our figures show that the majority of the reactions are weak. It is possible that Ritzmann's hypothesis only holds for the stronger reactions, and that the weaker ones arise from the fact that Waldenström's macroglobulinaemia usually occurs in the higher age groups, known to have a larger amount of false positive reactions (see Valkenburg, 1963c). The $\chi^{2}$ test, however, shows a significant difference from a group of normal elderly people. The difference from a group of unrelated diseases (not selected with respect to age) was not significant as far as the latex test was concerned, even if strong reactions were taken into account. If one considers that cases of Waldenström's macroglobulinaemia comprise persons who are old as well as diseased, not too much importance should be attached to the increased incidence of positive rheumatoid serology in this group. It should also be noted that most of the Waaler-Rose reactions in Waldenström's macroglobulinaemia were in the lowest titres that can be read and should therefore be considered with some caution. A comparison with a group of 105 elderly women with unrelated diseases showed an increase in positive Waaler-Rose tests in the Waldenström's group with $\chi^{2}=1.434(0.20<P<0.30)$. Although this control group cannot be regarded as unbiased, the results suggest that, in Waldenström's macroglobulinaemia, the number of Waaler-Rose tests is not significantly increased either. The many low Waaler-Rose titres might have some connexion with the so-called sludge phenomenon (clumping of erythrocytes) that is often observed in this disease.

It would appear, therefore, that a significantly increased incidence of positive reactions in tests for rheumatoid factors is associated with macroglobulinaemias of reactive origin, a result which could be expected if the rheumatoid factors themselves were of a reactive nature. The substrate specificity of these factors and the frequency of their occurrence would then depend on the nature of the change which the $\gamma$-globulin molecule has undergone by its binding to different antigens, as well as by the physical and chemical properties of the antigens themselves.

As a consequence it would seem to be important to investigate the properties which an antigen should have in order to elicit a lasting antibody response of IgM-globulin nature and the properties which an antigen-antibody complex should have to produce the same kind of reaction against its $\gamma$-globulin moiety.

\section{Summary}

(1) Sera from African patients with various kinds of reactive macroglobulinaemia and from European patients with IgM-paraproteinaemia were investigated in the latex-fixation test and the Waaler-Rose test, and compared with diseased control groups.

(2) Trypanosomiasis sera gave a significantly increased number of positive reactions, but only in the Waaler-Rose test.

(3) For chronic African splenomegaly and other forms of reactive macroglobulinaemia, an increase in positive reactions was observed but this was of lesser degree and not restricted to one type of test.

(4) Sera from cases of Waldenström's macroglobulinaemia did not give a significantly increased number of reactions in the latex-fixation test, when compared with diseased controls. The same is probably true for the Waaler-Rose test. 
(5) It appears that conditions accompanied by an increased level of reactive IgM-globulin in the serum give more false positive reactions, but that the nature of these conditions determines the level of significance as well as the substrate specificity of the rheumatoid serum factors.

The authors wish to thank Miss D. Lobez, Miss G. J. M. Lafeber, Miss B. J. v.d. Oord, and Miss P. J. van Bortel for their technical assistance. Dr. E. A. Loeliger, Dr. R. van Furth, and Dr. R. E. Ballieux kindly supplied the sera from patients with Waldenström's macroglobulinaemia. Helpful discussions with Dr. H. A. Valkenburg and Dr. W. Hijmans are gratefully acknowledged.

\section{REFERENCES}

Abruzzo, J. L., and Christian, C. L. (1961). J. exp. Med., 114, 791.

Aho, K., and Wager, O. (1961). Ann. Med. exp. Fenn., $39,79$.

Ball, J., De Graaff, R., Valkenburg, H. A., and Westendorp Boerma, F. (1962). Arthr. and Rheum., 5, 55.

Bartfeld, H. (1960). Ann. intern. Med., 52, 1059.

Bloomfield, N. (1960). J. Lab. clin. Med., 55, 73.

Bonomo, L., Tursi, A., and Pinto, L. (1963). Abstr. Commun. 5th Europ. Congr. Rheum. Dis. Stockholm, p. 22.

Cathcart, E. S., Williams, R. C., Ross, H., and Calkins, E. (1961). Amer. J. Med., 31, 758.

Charmot, G., Demarchi, J., Orio, J., Reynaud, R., and Vargues, R. (1959). Presse méd., 67, 11.

Coombs, R. R. A., Coombs, A. M., and Ingram, D. G. (1961). "The Serology of Conglutination." Blackwell, Oxford.

Eyquem, A., Guyot-Jeannin, N., and Podliachouk, L. (1959). Ann. Inst. Pasteur, 96, 295.

Francq, J. C., Eyquem, A., Podliachouk, L., and Jacqueline, F. (1960). Ibid., 98, 96.

Grubb, R., and Swahn, B. (1958). Acta path. microbiol. scand., 43, 305.

Hammack, W. J., and Holley, H. L. (1961). J. Lab. clin. Med., 58, 366.

Hijmans, W. (1963). In "The Epidemiology of Chronic Rheumatism", ed. J. H. Kellgren, vol. 1, p. 82. Blackwell, Oxford.

Ingram, D. G., Barber, H., McLean, D. M., Soltys, M. A., and Coombs, R. R. A. (1959). Immunology, 2, 268.

Kunkel, H. G., Simon, H. J., and Fudenberg, H. (1958). Arthr. and Rheum., 1, 289.

Mattern, P. (1962). Ann. Inst. Pasteur, 102, 64. (1964). Ibid., 107, 415.

—, Klein, F., Hijmans, W., and Radema, H. (1963). Méd. Afr. noire, 10, 241.

—, Masseyeff, R., Michel, R., and Peretti, P. (1961). Ann. Inst. Pasteur, 101, 382.

Milgrom, F., and Witebsky, E. (1960). J. Amer. med. Ass., 174, 56.

Ritzmann, S. E., and Levin, W. C. (1962). Tex. Rep. Biol. Med., 20, 236.

Singer, J. M., Plotz, C. M., Peralta, F. M., and Lyons, H. C. (1962). Ann. intern. Med., 56, 545.
Valkenburg, H. A. (1963a). In "The Epidemiology of Chronic Rheumatism", ed. J. H. Kellgren, vol. 1, p. 337. Blackwell, Oxford.

(1963b). Ibid., p. 330.

(1963c). Ibid., p. 74

and Hijmans, W. (1965). Unpublished data.

Waldenström, J., Winblad, S., Hällén, J., and Liungman, S. (1964). Acta med. scand., 176, 619.

Weitz, B. (1963). Ann. N.Y. Acad. Sci., 113, 400.

Williams, Jr., R. C., and Kunkel, H. G. (1962). J. clin. Invest., 41, 666.

Yorke, W. (1911). Ann. trop. Med. Parasit., 4, 529.

Facteurs rhumatoìdes dans la macroglobulinémie primaire et réactive

RÉSUMÉ

(1) Des sérums des africains atteints de divers types de macroglobulinémie et ceux des Européens atteints de IgM-paraprotéinémie furent étudiés par la réaction de Waaler-Rose et la réaction de fixation au latex, et comparés avec ceux des témoins malades.

(2) Les sérums trypanosomiques donnèrent un nombre significativement augmenté de réactions positives, mais seulement avec la réaction de Waaler-Rose.

(3) En ce qui concerne la splénomégalie africaine chronique et les autres formes de macroglobulinémie réactive, une augmentation du nombre des réactions positives fut observée, mais au moindre degré et sans limitation à un seul type de réaction.

(4) Les sérums des cas de macroglobulinémie de Waldenström ne donnèrent pas un nombre significative ment augmenté de réactions de fixation au latex page rapport aux témoins malades. Il en est probablement de même pour la réaction de Waaler-Rose.

(5) Il semble que les conditions accompagnées d'uñ taux augmenté de la globuline réactive IgM dans le sérum donnent plus de réactions positives fausses, mais c'est la nature de ces conditions qui détermine les limites de signification et la spécificité du corps réagissant du sérum rhumatoïde.

Factores reumatoides en la macroglobulinemia primaria y reactiva

\section{SUMARIO}

(1) Se investigaron sueros de africanos con varios tipos de macroglobulinemia y los de europeos con IgMparaproteinemia por la reacción de Waaler-Rose y la reacción de fijación de latex, comparándolos con los sueros de testigos enfermos.

(2) Los sueros tripanosómicos dieron un número significativamente aumentado de reacciones positivas, pero sólo con la reacción de Waaler-Rose.

(3) Cuanto a la esplenomegalia africana crónica y a otras formas de macroglobulinemia reactiva, también hubo un aumento de las reacciones positivas, pero menos pronunciado y sin limitarse a un solo tipo de reacción.

(4) Los sueros de los casos de macroglobulinemia de Waldenström no dieron un número significativamente aumentado de reacciones de fijación de latex en comparación con los testigos enfermos. Lo mismo se aplica probablemente a la reacción de Waaler-Rose.

(5) Parece que las condiciones acompañadas de cifras aumentadas de globulina reactiva IgM en el suero otorgan más reacciones positivas falsas, pero la naturaleza misma de estas condiciones es la que determina los límites de significación y la especifidad del substrato del suero reumatoide. 